\title{
Gene expression pattern of acetyl-coA carboxylase alpha, fatty acid synthase, and stearoyl-CoA desaturase in pregnant Barki sheep under complete feed deprivation
}

Ahmed A. El-Sayed ${ }^{1}$, Ahmed I. Ateya ${ }^{2}$, Mohamed F. Hamed ${ }^{3}$, Sherif M. Shoieb ${ }^{4}$, Hussam M. M. Ibrahim ${ }^{5}$, Maged R. El-ashker ${ }^{5}$, Mohamed A. Youssef ${ }^{5}$, Fathy Ibrahim ${ }^{1}$

${ }^{1}$ Department of Animal Health and Poultry, Desert Research Center, Matariya, Cairo, Egypt

${ }^{2}$ Department of Animal Husbandry and Animal Wealth Development, Faculty of Veterinary Medicine, Mansoura University, Mansoura 35516, Egypt ${ }^{3}$ Department of Pathology, Faculty of Veterinary Medicine, Mans oura University, Mansoura 35516, Egypt

${ }^{4}$ Veterinary Teaching Hospital, Faculty of Veterinary Medicine, Mansoura University, Mansoura 35516, Egypt

${ }^{5}$ Department of Internal Medicine and Infectious Diseases, Faculty of Veterinary Medicine, Mansoura University, Mansoura 35516, Egypt

\section{ARTICLE HISTORY}

Received: 17.07.2019

Revised: 19.08 .2019

Accepted: 21.08 .2019

Address correspondence to Hussam

Ibrahim; Tel. +201005290592;

E-mail: hussam-habosha@mans.edu.eg;

ORCID: https://orcid.org/0000-0002-

$3731-4586$

\section{ABSTRACT}

Objective: To assess the mRNA level of acetyl CoA carboxylase alpha (ACACA), fatty acid synthase (FASN), and stearoyl-CoA desaturase (SCD) by means of real-time PCR in Barki sheep subjected to complete feed deprivation.

Design: Controlled study.

Animals: Seven healthy pregnant ewes.

Procedures: Ewes were subjected to complete feed deprivation with ad libitum water for five consecutive days. Venous blood samples were collected from each ewe before (zero time) and on the fifth day post-deprivation of feed for measurement of the mRNA level of ACACA, FASN, and SCD and assessment of serum metabolic profile parameters.

Results: On the fifth day post-fasting, the gene expression pattern of ACACA, FASN, SCD genes showed a significant $(p<0.05)$ down regulation in comparison with pre-deprivation of feed. There was a significant $(p<0.05)$ increase in the serum level of non-esterified fatty acids (NEFA), beta-hydroxyl buteric acid (BHBA), and triglycerides in pregnant ewes in the fifth day post-fasting in comparison with predeprivation of feed. On the other hand, there was a significant $(p<0.05)$ decrease in the level of glucose, cholesterol, and insulin in pregnant ewes in the fifth day post-fasting compared with pre-deprivation of feed. On histopathology, liver showed marked heptic steatosis in midzonal and periportal area, with formation of small fatty cysts in liver lobule. There was a positive correlation between leptin and insulin $(r=0.996 ; p<0.01)$, BHB and leptin $(r=0.951 ; p<0.05)$ and glucose and SCD $(r=1.0, p<0.01)$. However, there was a negative correlation between FASN and NEFA ( $r=-0.991 ; p<0.05)$, FASN and leptin $(r=-0.683 ; p<0.05)$ and FASN and cholesterol $(r=-0.82 ; p<0.05)$.

Conclusion and clinical relevance: Pregnant Barki ewes can clinically tolerate complete feed deprivation for five days, with down regulation of ACACA, FASN, SCD genes and presence of marked metabolic changes. Therefore, metabolic monitoring is warranted to predict the early changes associated with feed deprivation under different stressful conditions.

Keywords: Barki sheep, ACACA, FASN, SCD, Feed deprivation.

\section{Abbreviations}

ACACA: AcetylCoA carboxylase alpha

FASN: Fatty acid synthase

SCD: Stearoyl-CoA desaturase

GAPDH: Glyceraldehyde 3-phosphate dehydrogenase

NEFA: Non-esterified fatty acid

BHBA: Beta-hydroxyl buteric acid

\section{INTRODUCTION}

Barki sheep, which dominate the north western desert of Egypt with population of 470,000 heads ( $11 \%$ of the total Egyptian sheep population) are known to be well adapted to the desert harsh conditions and scarce vegetation including poor feeding, heat stress [1]. The basic information on body conformation and productivity of Barki ewes are available [2].
Pregnancy toxemia often follows a state of negative energy balance with subsequent impaired gluconeogenesis, hypoglycemia, fat mobilization, ketonemia, and finally ketonuria [3-6]. It occurs in ewes carrying twins or triplets in the last month of pregnancy $[3$, 7].

ACACA, FASN, and SCD, lipid metabolism enzymes [8-11], have been studied during different levels of feed restriction in ram [12], lactating sheep [13] and in different sheep breeds [14]. They have been also studied in sheep under different stressful conditions as tail docking [15]. The variation in gene expression of several regulatory enzymes of the intermediary metabolism can provide useful tools to improve genetic selection toward livestock adaptation to harsh environments [12].

FASN is a part of multi-functional enzyme complex that catalyzes the synthes is of saturated fatty acids, including myristate, palmitate, and stearate $[10,11]$. It plays an important role in de 
novo lipogenesis in mammals, and is a key enzyme in the conversion of acetyl-CoA and malonyl-CoA to triglycerol $[11,13,16$, 17]. $S C D$, a rate-limiting enzyme, regulates the biosynthetic process of obtaining mono-unsaturated fatty acids from saturated fatty acids $[8,9]$. The acetyl-CoA carboxylase- $\alpha$ is a key regulated enzyme in de novo fatty acid synthesis which is decreased by feeding trans-10, cis-12 conjugated linoleic acid. In the ovine, the acetyl-CoA carboxylase- $\alpha$ gene is expressed from three ma in tissuespecific promoters (PI, PII and PIII) [13].

To the best of our knowledge, investigations on the lipid metabolism enzymes associated with complete feed deprivation in Barki sheep has not been reported. Therefore, the aim of the current study was to assess the mRNA level of lipid metabolism related markers, ACACA, FASN and SCD in Barki sheep subjected to complete feed deprivation.

\section{MATERIALS AND METHODS}

\subsection{Animals and management}

Seven healthy Barki ewes were studied (Age, 3.5 - 4 years; mean \pm standard deviation, $3.7 \pm 0.4$; weight, 23 - $36 \mathrm{~kg}$, mean \pm standard deviation, $29.5 \pm 4.8$ ). This study was conducted at Mariut Research Station, Desert Research Center, El-amria, Alexandria, Egypt. All procedures were done with the approval of the Ethical Committee of the Desert Research Center. Ewes were randomly selected and were subjected to daily clinical examination [18]. All ewes were naturally mated and were proved to be at $100-120$ days of pregnancy via ultrasonographic examination. Ewes under investigation were housed in semi open shaded pens. They were fed on mixture of concentrate ration, including hay (Trifolium alexantrinum) and rice or wheat straw over the year. The concentrates ration mixture, with $17-18 \%$ crude protein, consisted of cottonseed cake, maize, soya bean, wheat or rice bran, and supplemented with suitable mineral mixture e.g. magnesium oxide, calcium carbonate, and sodium chloride (1:2:2). All ewes fed on 0.5 $\mathrm{kg}$ of concentrate / day at 2 month gestation, increasing to $0.75 \mathrm{~kg}$ / day for the last 4 weeks of pregnancy according to NRC [19]. Rational, natural pasture (green herbage, and grasses) was fed when available. Clean water source was available for all studied ewes all the day.

\subsection{Study design}

Six weeks prior to the expected date of parturition, the selected ewes were housed in separated pens containing straw bedding. After a period of two weeks adaptation time, the ewes were subjected to complete feed deprivation for five consecutive days $[20,21]$. Meanwhile, clean water was offered ad libitum throughout the study period.

\subsection{Blood samples}

Two blood samples, $5 \mathrm{ml}$ each, were collected from each ewe before (zero time) and on the fifth day post deprivation of feed. One sample was collected into tube containing ethylenediaminetetraacetic acid (EDTA) as anti-coagulant for collection of whole blood necessary for detection of mRNA level of ACACA, FASN and SCD genes. The other sample was collected into plan sterile tube for separation of serum which was kept frozen at 20 oC until analysis of serum metabolic profile.

\subsection{RNA extraction and reverse transcription}

Total RNA was extracted from whole blood sample using Direct-zol RNA Kits according to the manufacturer's instructions
(Direct-zolTM RNA MiniPrep, Zymo-research, USA, catalog No. R2050). The quantity and purity were measured by using a nanospectrophotometer (UV-Vis spectrophotometer Q5000, Thermofischer, USA) and the integrity was evaluated by gel electrophoresis. The cDNA of each sample was synthesized following the manufacture protocol (SensiFastTMcDNA synthesis kit, Bioline, catlog No. Bio-65053). The reaction mixture was carried out in a total volume $20 \mu \mathrm{L}$ consisted of total RNA up to $1 \mu \mathrm{g}, 4 \mu \mathrm{L}$ 5x TransAmp buffer, $1 \mu \mathrm{L}$ reverse transcriptase and DNase freewater up to $20 \mu \mathrm{L}$. The final reaction mixture was placed in a thermal cycler and the following program was carried out; primer annealing at $25^{\circ} \mathrm{C}$ for 10 minutes, reverse transcription at $42^{\circ} \mathrm{C}$ for 15 minutes followed by inactivation at $85^{\circ} \mathrm{C}$ for 5 minutes. The samples were held at $4^{\circ} \mathrm{C}$.

\subsection{Quantitative Real Time PCR}

Relative quantification of mRNA level of ACACA, FACN and SCD in sheep blood was performed by real-time PCR using SYBR Green PCR Master Mix (2x SensiFastTM SYBR, Bioline, catlog No. Bio-98002). Primer sequences, annealing temperature and the size of each amplified PCR product are shown in table (1). The house keeping gene GAPDH was used as an internal control. The reaction mixture was carried out in a total volume $20 \mu \mathrm{L}$ consisted of $10 \mu \mathrm{L}$ $2 x$ SensiFast SYBR, $3 \mu \mathrm{L} \mathrm{cDNA}, 5.4 \mu \mathrm{l} \mathrm{H} 2 \mathrm{O}$ (d.d water), $0.8 \mu \mathrm{l}$ of each primer. The PCR cycling conditions were as follows: denaturation program $94^{\circ} \mathrm{C}$ for two minutes; amplification and quantification program repeated 40 cycles of denaturation temperature $94^{\circ} \mathrm{C}$ for 10 seconds, annealing temperature for 30 seconds (Table 1 ), and extension temperature $72^{\circ} \mathrm{C}$ for 20 seconds. At the end of the amplification phase, a melting curve analysis was performed to confirm the specificity of the PCR product. The relative expression of the gene in each sample versus a control in comparison to GAPDH gene and calculated according to the 2- $\Delta \Delta \mathrm{Ct}$ method [22].

\subsection{Metabolic profile}

Glucose, cholesterol and triglycerides levels were measured using the commercial test kits supplied by Chronolab (Chronolab chemicals, Barcelona, Spain) (Ref. No. 101-0014, 101-0576 and 101-0241, respectively). For measurement of BHBA level, a commercial test kit supplied by Ben (Ben Chemicals, Pakistan) (Ref. No. HB8855) was used. Leptin and insulin levels were measured using commercial test kits supplied by SinoGeneClon (Sino Gene Clon, Hangzhou, China) (sheep leptin ELISA kit, Catalog No: SG5010) and BioSystems (BioSystems S.A., Barcelona, Spain) (Enzymatic Immunoassay Test Kit, Catalog No. 10801), respectively. Serum NEFA level was determined chemically according to standard method.

\subsection{Histopathology}

Liver biopsy samples were obtained from each ewe under strict aseptic conditions before experiment and at the fifth day post deprivation of feed. Liver biopsy was obtained under infiltrative local anesthesia with $2 \%$ lidocaine with ultrasound guidance [23]. To avoid the risk of bleeding during and after liver biopsy, all sampled ewes must be injected with phytomenadione (Konakion MM 10 mg/ml, F. Hoffmann-La Roche Ltd., Basel, Switzerland) at a dose of 1 ampoule / animal as IV injection and ethamsylate (Dicynone $250 \mathrm{mg}$ injection solution, OM PHARMA, 22, rue du Bois du-Lan, 1217 Meyrin 2/Geneva, Switzerland) at a dose of 2 ampoules / animal as IM injection. Ewes were restrained in the right lateral position and the liver ultrasonography was carried out from the $8^{\text {th }}$ to $12^{\text {th }}$ intercostal space on the right flank. Ewes subjected to biopsy were kept under close observation for a period 
of 6 hours post-procedure and ultrasonography was conducted to assess the presence of hematoma or active bleeding. Liver specimens were processed according to standard histopathological techniques and lipidosis was assessed in stained liver sections [24, 25].

\subsection{Clinical follow up}

All animals were examined clinically twice daily to detect the evidence of any clinical abnormalities.

\subsection{Statistical analysis}

Statistical analyses were carried out by using a statistical software package (SPSS for windows, version 17, USA). Firstly, Shapiro test was performed to assess the normality distribution of the data. Because the data were found normally distributed, mean and standard deviation of each variable were calculated. Unpaired t-test was used to test the differences between parameters pre and post-feed deprivation. Pearson correlation was performed to assess the correlation between biochemical parameters and gene expression of tested enzymes. Correlation coefficient $(r)$ and $p$ value were considered. For all results were considered significant only at $p<0.05$.

\section{RESULTS}

The ewes showed no detectable clinical signs and remain clinically healthy throughout the study period. Furthermore, liver biopsy procedures provided no adverse consequences. Clinical follow up showed that all ewes delivered their lambs normally without any medical problem

Gene expression pattern results showed a significant ( $p<$ $0.05)$ down regulation of ACACA (0.69 \pm 0.17 vs $0.22 \pm 0.03)$, FASN $(0.28 \pm 0.16$ vs $0.18 \pm 0.03)$, and SCD $(1.05 \pm 0.1$ vs $0.19 \pm 0.02)$ in ewes on the fifth day of deprivation of feed in comparison with pre-deprivation of feed (Figure 1).

On the fifth day of experiment in comparison with prefasting, there was a significant $(p<0.05)$ increase in the serum level of NEFA, BHBA, and triglycerides. On the other hand, there was a significant $(p<0.05)$ decrease in the serum level of glucose, cholesterol, and insulin. However, leptin level did not change significantly on the fifth day post-fasting compared with pre-fasting level.

Liver of ewes at fifth day of fasting showed a severe hepticsteatosis in midzonal and periportal area, rupture of hepatocytes with formation of small fatty cysts in liver lobule (Figure 2).

Regarding the correlation between lipid metabolism enzymes and biochemical parameters, there was a positive correlation between leptin and insulin ( $r=0.996 ; \quad P<0.01)$, BHB and leptin ( $r=0.951 ; P<0.05)$ and glucose and SCD $(r=1.0, P<0.01)$. However, there was a negative correlation between FASN and NEFA ( $r=-0.991, P<0.05)$, FASN and leptin $(r=-0.683 ; P<0.05)$ and FASN and cholesterol $(r=-0.82 ; P<0.05)$.
Table 1. Oligonucleotide primers sequence, annealing temperature and PCR product size of the stued genes.

\begin{tabular}{|c|c|c|c|c|}
\hline Gene & Oligonucleotide sequence & $\begin{array}{l}\text { Accession } \\
\text { number }\end{array}$ & $\begin{array}{l}\text { Annealing } \\
\text { temp }\left({ }^{\circ} \mathrm{C}\right)\end{array}$ & $\begin{array}{l}\text { Size } \\
\text { (bp) }\end{array}$ \\
\hline \multirow[t]{2}{*}{ ACACA } & f5'- ATGTGGCCTGGGTAGATCCT-3' & NM_0010 & 60 & 26 \\
\hline & r5'-ACGTAACACAAGGCTGATGGTG-3' & 09256.1 & & 1 \\
\hline \multirow[t]{2}{*}{ FASN } & f5'- GGAAGGCGGGACTATATGGC-3' & XM_0040 & 62 & 27 \\
\hline & r5'- CATGCTGTAGCCTACGAGGG-3, & 13447.1 & & 8 \\
\hline \multirow[t]{2}{*}{ SCN } & f5'- GGCGTTCCAGAATGACGTाT-3, & NM_0010 & 58 & 25 \\
\hline & r5'- TGAAGCACAACAGCAGGACA-3' & $092 \overline{5} 4.1$ & & 1 \\
\hline GAPDH & $\begin{array}{l}\text { f5'- TGACCCCTTCATTGACCTTC-3, } \\
\text { r5'- GATCTCGCTCCTGGAAGAG-3, }\end{array}$ & $\begin{array}{l}\text { NM- } \\
00103403 \\
4\end{array}$ & 62 & $\begin{array}{l}14 \\
3\end{array}$ \\
\hline
\end{tabular}

ACACA $=$ AcetylCoA carboxylase alpha; FASN = Fatty Acid Synthase SCD = Stearoyl-Coa Desaturase ( $\triangle$-9-desaturase); GAPDH = Glyceraldehyde 3-Phosphate Dehydrogenase.

Table 2. Biochemical parameters (mean $\pm S D$ ) pre-and postcomplete feed deprivation in Barki ewes.

\begin{tabular}{lll} 
Variable & \multicolumn{2}{c}{ Time post-feed deprivation (day) } \\
\cline { 2 - 3 } & 0 & 5 \\
NEFA $(\mathrm{mmol} / \mathrm{l})$ & $2.10 \pm 0.08^{\mathrm{a}}$ & $2.53 \pm 0.1^{\mathrm{b}}$ \\
BHBA (mmol/l) & $0.38 \pm 0.35^{\mathrm{a}}$ & $2.35 \pm 0.1^{\mathrm{b}}$ \\
Glucose $(\mathrm{mmol} / \mathrm{l})$ & $3.25 \pm 0.06^{\mathrm{a}}$ & $0.78 \pm 0.1^{\mathrm{b}}$ \\
Cholesterol $(\mathrm{mmol} / \mathrm{l})$ & $2.97 \pm 0.11^{\mathrm{a}}$ & $2.16 \pm 0.1^{\mathrm{b}}$ \\
Triglyceride $(\mathrm{mmol} / \mathrm{l})$ & $1.12 \pm 0.08^{\mathrm{a}}$ & $1.19 \pm 0.01^{\mathrm{b}}$ \\
Insulin $(\mu \mathrm{IU} / \mathrm{ml})$ & $0.95 \pm 0.04^{\mathrm{a}}$ & $0.70 \pm 0.1^{\mathrm{b}}$ \\
Leptin $(\mathrm{ug} / \mathrm{l})$ & $17.2 \pm 2.89^{\mathrm{a}}$ & $14.01 \pm 0.3^{\mathrm{b}}$
\end{tabular}

a,b: Means in the same raw with different superscript letters are significantly different at $\mathrm{p}<0.05$. NEFA, non esterified fatty acid; BHBA, beta hydroxyl buteric acid.

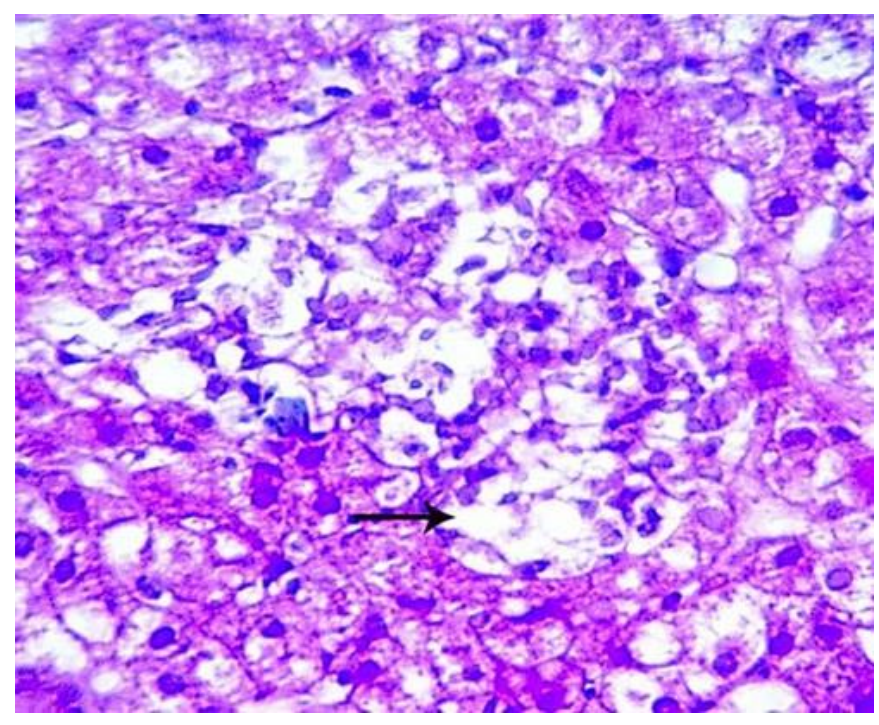

Figure 2. Liver of ewe five days post-feed deprivation, shows moderate to severe degree of lipidosis (arrow). 

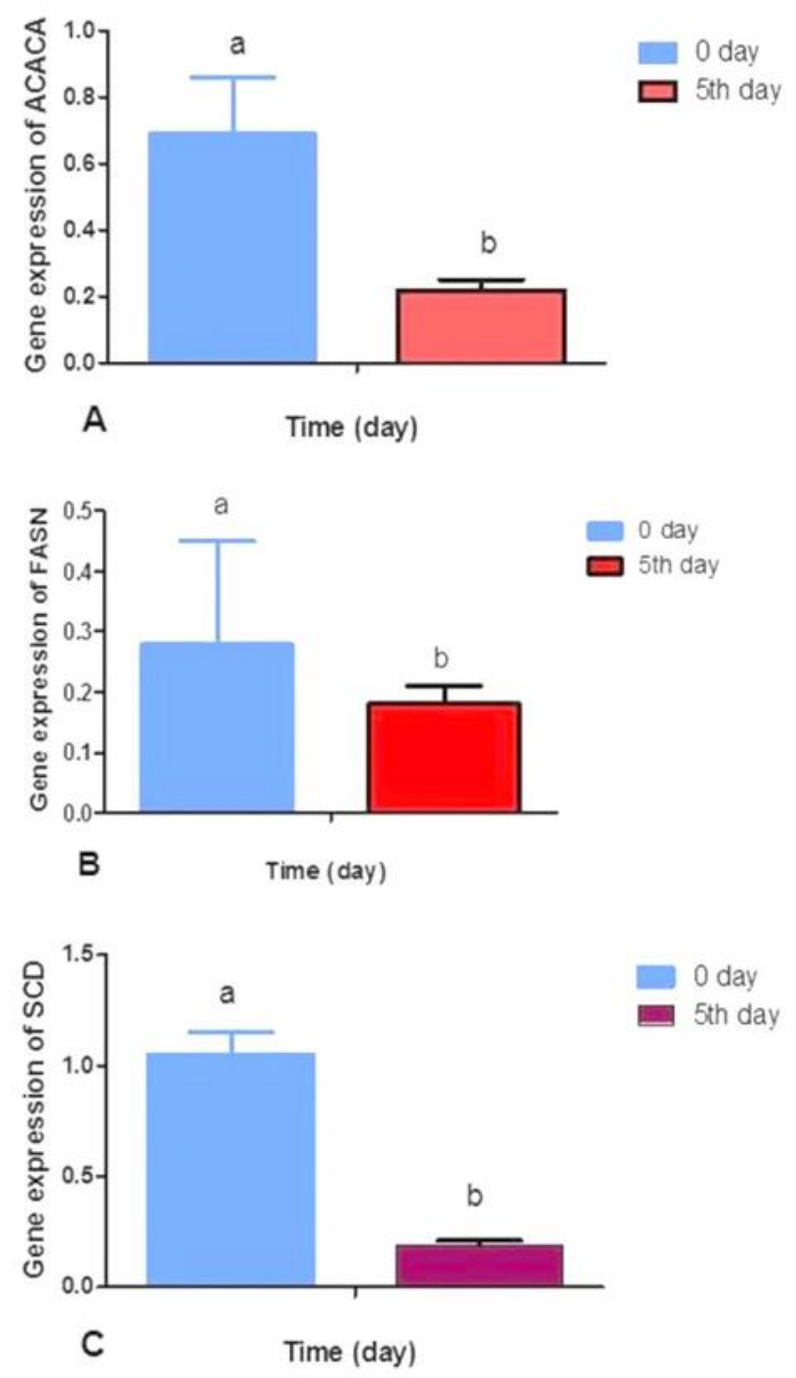

Figure 1. mRNA level of ACACA (A), FASN (B) and $S C D(C)$ in Barki sheep under complete feed deprivation. ACACA=AcetylCoA carboxylase alpha, FASN= Fatty acid synthase, $S C D=S$ tearoyl-CoA desaturase.

\section{DISCUSSION}

Feeding level and nutrient availability, may affect glucose uptake and utilization in sheep [26] The effect of long term underand over-feeding on the expression of genes related to lipid metabolism [26] and major milk proteins' genes [27] in the mammary tissue of small ruminants have been described. However, little information on the effect of complete feed deprivation on gene expression of genes related to lipid metabolism in pregnant sheep is not available. Therefore, our work aimed to assess the mRNA level of ACACA, FASN, SCD markers in Barki sheep subjected to complete feed deprivation.

Clinically, there was no evidence for abnormal signs, where there were no behavioral abnormalities. The temperature, heart and respiratory rates were similar to the normal reference values $[28,29]$. However, a significant down regulation of lipogenic metabolic marker genes (ACACA, FASN, SCD genes was documented. Similarly, FAS, which represents one of the regulatory enzymes involved in fatty acid synthesis, showed down regulation of mRNA level in partial feed restriction (4.47 times lower for Australian Merino sheep and 6.33 times lower for the Dorper sheep) [12]. In mammary tissue of underfed sheep, a significant reduction of mRNA level of ACCA, FAS, LPL (lipoprotein lipase) and SCD in the mammary tissue was recorded [26]. Furthermore, the negative, compared to positive, energy balance in sheep down-regulates ACACA, FAS and SCD expression in their mammary tissue which indicates that the decrease in nutrient availability may lead to lower rates of lipid synthesis. Additionally, in mice with dietary feed restriction, mRNA level of FAS and ACACA was decreased [30].

The differences found in gene expression of several regulatory enzymes of the intermediary metabolism can provide us eful tools, leading to improved genetic selection toward livestock adaptation to harsh environments [12].

The changes in fatty acid profile due to feeding system resulted in changes in the expression pattern of genes associated with fat metabolism in sheep [31]. In the same respect, SNP in ACACA gene affects fat content in sheep milk indicating that such gene is a potential marker for fat metabolism [32]. Previous studies reported the elucidated effect of such markers in various domestic animals suggesting a prospective role of SCD in the control of body weight and energy homeostasis in chickens [33]. Moreover, the association between single nucleotide polymorphisms in bovine SCD and FASN genes with fatty acid composition in commercial cross-bred beef steers has been documented [34]. Accordingly, SCD and FASN have been found to be potential candidate genes influencing fatty acid composition in beef cattle. In dairy cattle, the high expression of SCD1 in the mammary gland is relevant for the fatty a cid composition of milk and dairy products [35].

Interestingly, down regulation of SCD was found to have a positive correlation with serum glucose level in feed deprived ewes. However, FASN recorded a negative correlation with NEFA, leptin and cholesterol. These enzymes have an important role in the lipogenesis, which may be affected by feed deprivation. FASN was found to be a key enzyme in the conversion of acetyl-CoA and malonyl-CoA to triglycerol $[11,13,16,17]$. Moreover, SCD has a key role in the saturated fatty acid synthesis.

In an experiment, regulation of hepatocellular fatty acid uptake in mouse models of fatty liver disease showed that there was a high correlation between hepatic steatosis and expression of long chain fatty acid enzymes (SCD-1, FASN) [36]. Unfortunately, in our study, estimation of degree of fatty acid uptake by liver was not performed. In addition, the response of liver to feed deprivation in sheep may be completely differed from that occur during hepatic steatosis in other animals or human.

Although there were no clinical or behavioral abnormalities at the fifth day post-feed deprivation, the mean value of plasma glucose was significantly decreased in all ewes on the fifth day of feed deprivation, suggesting a case of subclinical pregnancy toxemia. This finding is in accordance with that reported previously $[37,38]$. The importance of glucose in the pregnant ewes as a major source of energy for the fetus is well known. Therefore, pregnant ewes are at high risk of developing pregnancy toxemia when glucose level is affected. The significant decrease of serum insulin concentrations on the fifth day post-fasting may be explained either by a slower insulin release from the pancreas [39] or by a higher clearance of blood insulin by the liver [40]. Low serum insulin induces a fat mobilization, a lowered transport of blood glucose to tissues and a change in liver metabolism of fatty acids from the synthesis of triglycerides to the synthesis of ketone bodies [41]. 
The mean value of serum BHB and NEFA showed marked elevation on the fifth day of feed deprivation in comparison with pre-fasting. Lipolysis and the release of long chain fatty acids, with subsequent formation of ketones may be an explanation [42]. Fasting was also found to induce NEFA mobilization $[43,44]$. In the same context, fat infiltration of the liver and a low output of lipoprotein explain the low serum level of cholesterol. Similar finding has been reported in cows [45]. The increased serum triglycerides at the fifth day of deprivation of feed may be due to lipolysis with subsequent release of long chain fatty acids, which are stored as triglycerides in the liver or converted to ketone bodies. Such finding was described in goats [46]. On the other hand, triglycerides level in cows with moderate to severe fatty liver was not different from healthy cows [47].

The present result showed a positive correlation between leptin and BHB and between leptin and insulin. In cows, there is a controversy about the correlation between leptin and BHB during transition period. There was no correlation has been reported in earlier study [48]. However, a negative correlation between leptin and BHB was recorded in cows at peri-parturient period [49]. Regarding the correlation between insulin and leptin, similar finding has been recorded in normoketonemic dairy cows [48].

In the present study, liver biopsy was obtained without any complications. In sheep, it was proposed that serial liver biopsy doesn't have any effect on hematologic, histologic or serum biochemical parameters [50]. On contrary, several complications were evident in calves [51]. Hepatic lipidosis and necrosis of hepatocytes were evident at the fifth day of feed deprivation. This finding was adjunct with biochemical changes, but, didn't reflect clinical signs, suggesting the significance of metabolic profile monitoring rather than clinical approach. However, the use of a single biochemical or histopathologic criterion to define the degree of hepatic lipidosis in ketotic cows resulted in misidentification [24].

The present study showed some limitations, which should be considered in future studies. Firstly, the effect of pregnancy with twins or triplets on gene expression of selected enzymes was not studied. Secondly, the clinical and biochemical investigation were conducted at zero and fifth day of investigation, which doesn't allow identification of the exact time of changes. Further investigation need to be applied at frequent and short intervals to explore the early metabolic changes associated with complete feed deprivation. Thirdly, the present study was conducted as experimental work, which may not extrapolate with that of clinical cases. Therefore, a further study is required to assess the gene expression of studied enzymes in diseased ewes under field conditions. Fourthly, limited number of enzymes was studied, which don't elucidate the complex metabolic response to feed deprivation in ewes. Therefore wide range of parameters shouldbe considered in future studies.

Conclusion: The present study indicates that pregnant Barki sheep can clinically tolerate complete feed deprivation for five days, in spite of down regulation of ACACA, FASN, SCD genes and presence of marked metabolic changes. In Barki sheep, metabolic monitoring is recommended to predict the early changes associated with feed deprivation under different stressful conditions.

Declaration: All authors gave their informed consent prior to their inclusion in the study.

Conflict of Interest statement: The authors declare that they have no conflict of interest.
Ethical approval: All applicable international, national, and/or institutional guidelines for the care and use of animals were followed.

\section{REFERENCES}

[1] El-Wakil SI, Shemeis AR, Ahmed AM, Abdallah. Genetic and phenotypic relationships involving body weight, degree of maturity and measurer of gain rate of Barki sheep without having recourse to fitting growth curves. J Agricult Sci, Mansoura Univ 2008;33:4835-48.

[2] Ragab M, Ghoneim K. Wool characteristics of the Barki sheep. J Anim Prod UAR 1961;1:23-6.

[3] Rook JS. Pregnancy toxemia of ewes, does, and beef cows. Vet Clin North Am Food Anim Pract 2000;16:293-317.

[4] Henze P, Bickhardt K, Fuhrmann H, Sallmann HP. Spontaneous pregnancy toxaemia (ketosis) in sheep and the role of insulin Zentralbl Veterinarmed A. 1998;45:255-66.

[5] Van Saun RJ. Pregnancy toxemia in a flock of sheep. J Am Vet Med Assoc 2000;217:1536-9.

[6] Kulcsar M, Danko G, Delavaud C, Mircu C, Nikolic AJ, Gaspardy A, et al. Endocrine characteristics of late pregnant hyperketonaemic ewes and their reproductive performance following the induction of ovarian cyclicity out of the breeding season. Acta Vet Hung 2006;54:235-49.

[7] Radostit OM, Gay CC, Hinchcliff KW, Constable PD. Veterinary medicine. 10th Edn ed. Spain: Saunders Elsevier, 2007. p. 1668.

[8] Kaestner KH, Ntambi J, Kelly T, Lane M. Differentiation-induced gene expression in 3T3-L1 preadipocytes. A second differentially expressed gene encoding stearoyl-CoA desaturase. J Biol Chem 1989;264:1475561.

[9] Mele M, Conte G, Castiglioni B, Chessa S, Macciotta NPP, Serra A, et al. Stearoyl-coenzyme A desaturase gene polymorphism and milk fatty acid composition in Italian Holsteins. J Dairy Sci 2007;90:4458-65.

[10] Roy R, Ordovas L, Zaragoza P, Romero A, Moreno C, Altarriba J, et al. Association of polymorphisms in the bovine FASN gene with milk-fat content. Anim Genet 2006;37:215-8.

[11] Smith S, Witkowski A, Joshi AK. Structural and functional organization of the animal fatty acid synthase. Prog lipid Res 2003;42:289-317.

[12] Van Harten S, Brito R, Almeida A, Scanlon T, Kilminster T, Milton J, et al. Gene expression of regulatory enzymes involved in the intermediate metabolism of sheep subjected to feed restriction. Anima 2013; 7:439-45

[13] Ticiani E, Urio M, Ferreira R, Harvatine K, De Oliveira D. Transcriptional regulation of acetyl-CoA carboxylase $\alpha$ isoforms in dairy ewes during conjugated linoleic acid induced milk fat depression. Animal 2016:1-7.

[14] Mohammad SI, Ali NA, Reza NM, Reza MH, Reza V. Evaluation of SCD and FASN Gene Expression in Baluchi, Iran-Black, and Arman Sheep. Rep Biochem Mol Biol 2016;5:33.

[15] Yue Y, Cheng X, Zhao S, Liu Z, Liu L, Zhou R, et al. Effects of tail docking on the expression of genes related to lipid metabolism in Lanzhou fattailed sheep. Genet Mol Res 2016;15.

[16] Semenkovich CF. Regulation of fatty acid synthase (FAS). PROG LIPID RES 1997;36:43-53.

[17] Yan X, Wang $Y, X u Z$. Regulation of fatty acid synthase (FAS) gene expression in animals. Acta Zoonutrimenta Sinica 2002;2.

[18] Pugh DG, Baird N. sheep and goat medicine. In: Company S, editor. 2nd Edn ed. Philadelphia, London2012.

[19] NRC. Nutrient requirements of dairy cattle. 7th Revised Edition, Subcommittee on Dairy Cattle Nutrition, Committee on Animal Nutrition, Board on Agriculture and Natural Resources, National Research Council, National Academy Press, Washington, D.C. 20418, 2001.

[20] Gonzalez FH, Hernandez F, Madrid J, Martinez-Subiela S, Ceron JJ, Tecles F. Acid-base and electrolyte status during early induced pregnancy toxaemia in goats. Vet J 2012;193:598-9.

[21] Gonzalez FH, Hernandez F, Madrid J, Martinez-Subiela S, Tvarijonaviciute A, Ceron JJ, et al. Acute phase proteins in experimentally induced pregnancy toxemia in goats. J Vet Diagn Invest 2011;23:57-62

[22] Pfaffl MW. A new mathematical model for relative quantification in real-time RT-PCR Nucleic Acids Res 2001;29. 
[23] Melo CH, Sousa FC, Batista RI, Sanchez DJ, Souza-Fabjan JM, Freitas VJ, Melo LM, Teixeira DI. Comparative analysis of laparoscopic and ultrasound-guided biopsy methods for gene expression analysis in transgenic goats. Genet Mol Res 2015; 14:8672-84.

[24] Cebra CK, Garry FB, Getzy DM, Fettman MJ. Hepatic lipidosis in anorectic, lactating Holstein cattle: a retrospective study of serum biochemical abnormalities. J Vet Intern Med 1997;11:231-7.

[25] Johnson EH, Al-Habsi K, Kaplan E, Srikandakumar A, Kadim IT, Annamalai $\mathrm{K}$, et al. Caprine hepatic lipidosis induced through the intake of low levels of dietary cobalt. Vet J 2004;168:174-9.

[26] Tsiplakou E, Flemetakis E, Kouri E-D, Sotirakoglou K, Zervas G. The effect of long term under-and over-feeding on the expression of genes related to lipid metabolism in mammary tissue of sheep. J Dairy Res 2015;82:107-12.

[27] Tsiplakou E, Flemetakis E, Kouri ED, Karalias G, Sotirakoglou K, Zervas G. The effect of long-term under-and overfeeding on the expression of six major milk proteins' genes in the mammary tissue of goats. Journal of animal physiology and animal nutrition. 2015.

[28] Yildiz A, Balikci E, Gurdogan F. Serum mineral levels at pregnancy and postpartum in single and twin pregnant sheep. Biol Trace Elem Res 2005; 107:247-54

[29] Balıkcı E, Yıldız A, Gürdoğan F. Blood metabolite concentrations during pregnancy and postpartum in Akkaraman ewes. Small Rumin Res 2007; 67:247-51

[30] Kim T-S, Freake HC. High carbohydrate diet and starvation regulate lipogenic mRNA in rats in a tissue-specific manner. Journal Nut 1996;126:611.

[31] Dervishi E, Serrano C, Joy M, Serrano M, Rodellar C, Calvo J. The effect of feeding system in the expression of genes related with fat metabolism in semitendinous muscle in sheep. Meat Sci 2011;89:91-7.

[32] Moioli B, Scatà M, Matteis G, Annicchiarico G, Catillo G, Napolitano F. The ACACA gene is a potential candidate gene for fat content in sheep milk. Anim genet 2013;44:601-3.

[33] Dridi S, Taouis M, Gertler A, Decuypere E, Buyse J. The regulation of stearoyl-CoA desaturase gene expression is tissue specific in chickens. J Endocrinol 2007;192:229-36.

[34] Yokota S, Sugita H, Ardiyanti A, Shoji N, Nakajima H, Hosono M, et al. Contributions of FASN and SCD gene polymorphisms on fatty acid composition in muscle from Japanese Black cattle. Anim genet 2012;43:790-2.

[35] di Martino O, Troiano A, Addi L, Guarino A, Calabro S, Tudisco R, et al. Regulation of stearoyl coenzyme A desaturase 1 gene promoter in bovine mammary cells. Anim Biotechnol 2015;26:251-9.

[36] Jasmine FG, Walewski J, Anglade D, Berk P. Regulation of Hepatocellular Fatty Acid Uptake in Mouse Models of Fatty Liver Disease with and without Functional Leptin Signaling: Roles of NfKB and SREBP-1C and the Effects of Spexin. Seminars in Liver Disease: Thieme Medical Publishers; 2016. p. 360-72.

[37] Hefnawy AE, Youssef $S$, Shousha S. Some immunohormonal changes in experimentally pregnant toxemic goats. Vet Med Int 2010;768438:16.

[38] Abdelaal A, Gouda SM, Tharwat M. Clinico-biochemical, ultrasonographic and pathological findings of hepatic abscess in feedlot cattle and buffaloes. Vet World 2014;7:306-10.
[39] Lipson LG, Siegei E, Wollheim CB, Sharp W. Insulin release during fasting: studies on adenylate cyclase, phosphodiesterase, protein kinase, and phosphoprotein phosphatase in isolated islets of Langerhans of the rat. Endocrinol 1979;105:702-7.

[40] Striffler JS, Curry DL. Effect of fasting on insulin removal by liver of perfused liver-pancreas. Abbreviation: Am J Physiol Endocrinol Metab 1979;237:E349.

[41] Witters L, Trasko CS. Regulation of hepatic free fatty acid metabolism by glucagon and insulin. Abbreviation: Am J Physiol Endocrinol Metab 1979;237:E23.

[42] Roubies N, Polizopoulou Z, Minas A, Papasteriades A. A pre-and postpartum study of selected biochemical parameters in ewes for the early detection of pregnancy toxemia (In Greek and English). J Hellenic Vet Med Soc 2003; $54: 11-20$

[43] Ametaj B. new understanding of the causes of fatty liver in dairy cows Advances in dairy technology: proceedings of the Western Canadian Dairy Seminar 2005; 17:97.

[44] Scott P, Sargison N, Penny C. Evaluation of recombinant bovine somatotropin in the treatment of ovine pregnancy toxaemia. Vet 1998; 155:197-9.

[45] Sevinç M, Başoğlu A, Güzelbektaş H, Boydak M. Lipid and lipoprotein levels in dairy cows with fatty liver. Turkish J Vet Anim Sci 2003;27:295-9.

[46] Barakat S, Al-Bhanasawi N, Elazhari G, Bakhiet A. Clinical and serobiochemical studies on naturally occurring pregnancy toxaemia in Shamia goats. J Anim Vet Adv 2007;6:768-72.

[47] Drackley JK, Overton TR, Douglas GN. Adaptations of glucose and long chain fatty acid metabolism in liver of dairy cows during the periparturient period. J Dairy Sci 2001;84:E100-E12.

[48] Kerestes M, Faigl V, Kulcsár M, Balogh O, Földi J, Fébel H, et al. Periparturient insulin secretion and whole-body insulin responsiveness in dairy cows showing various forms of ketone pattern with or without puerperal metritis. Domestic Anim Endocrino 2009;37:250-61.

[49] Nowroozi-Asl A, Aarabi N, Rowshan-Ghasrodashti A. Ghrelin and its correlation with leptin, energy related metabolites and thyroida hormones in dairy cows in transitional period. Polish JU Vet Sc 2016;19:197-204

[50] Harvey R, Lovering S, Bailey E, Norman J. The influence of multiple liver biopsies on hematologic and serum biochemical values of sheep. The Cornell Vet 1984; 74:322-30.

[51] Swanson K, Merchen N, Erdman J, Drackley J, Orias F, Douglas G, et al. Technical note: a technique for multiple liver biopsies in neonata calves. J Anim Sci. 2000;78:2459-63. 